\title{
DEVELOPMENT OF LUNG FLUKE, Paragonimus heterotremus, IN RAT AND MICE, AND THE ROLE OF PARATENIC HOST IN ITS LIFE CYCLE
}

\author{
Pham Ngoc Doanh ${ }^{1 *}$, Hoang Van Hien ${ }^{1}$, Pham Thanh $\mathrm{An}^{2}$, Luu Anh Tu ${ }^{3}$ \\ ${ }^{1}$ Institute of Ecology and Biological Resources, VAST, *pndoanh@yahoo.com \\ ${ }^{2}$ Noi Bai Animal Quarantine Station \\ ${ }^{3}$ National Lung Hospital
}

\begin{abstract}
Lung fluke, Paragonimus heterotremus, has been identified as the important pathogen for human paragonimiasis in Vietnam. Eating under cooked mountain crabs, which are contaminated with $P$. heterotremus metacercariae, is confirmed as the route of infection. In this study, we identified the role of paratenic host in the life cycle of $P$. heterotremus by experimental infection to house rat (Rattus tanizumi) and mice BALB/c, and then transferred to cats. The results showed that $P$. heterotremus metacercariae developed to adults in the lungs of rats. In contrast, they remain as juvenile worms in liver and muscles of mice. These juveniles developed to adults when they were transferred to cats, confirming that mice serve as the role of paratenic hosts in the life cycle of $P$. heterotremus in Vietnam. Thus, investigation for natural paratenic hosts of $P$. heterotremus is necessary, and not eating uncooked/undercooked meat of other animals in addition to mountain crabs should be added to prevention of paragonimus infection. Development of different size metacercariae of $P$. heterotremus in rats and mice were also discussed herein.
\end{abstract}

Keywords: Paragonimus heterotremus, development, paratenic host, rat and mice.

\section{INTRODUCTION}

Lung fluke of the genus Paragonimus, which parasite the lungs of human and animals, cause serious affection on the health of infected individuals $[1,2]$. Infection occurs by eating uncooked/undercooked mountain crabs (the second intermediate hosts) infected with metacercariae or by consumption of raw/undercooked meat of paratenic hosts that harbor juvenile worms [2]. Paratenic hosts have been reported in the life cycle of some Paragonimus species, such as, $P$. westermani, P. heterotremus, P. kellicotti, $P$. mexicanus and P. skrjabini [2]. Paratenic hosts of Paragonimus species are usually mammals and rodents are common paratenic hosts in experiments.

In Vietnam, seven Paragonimus species have been detected in Northern and Central provinces so far [4]. Of these, only $P$. heterotremus has been proved to infect humans in Northern provinces $[4,5,12]$. The habit of eating raw/undercooked mountain crab hosts was identified as the way of infection. To date, there has been no a study on the role of paratenic hosts in the life cycle of $P$. heterotremus in Vietnam. Moreover, morphological studies showed variation of $P$. heterotremus metacercariae [6], including metacercariae as small as those of $P$. pseudoheterotremus which can be matured in rats [21]. This raises a question of whether there are differences among the development of different-size metacercariae of $P$. heterotremus in rats. Above mentioned issues will be tested in this study.

\section{MATERIALS AND METHODS}

Metacercariae of $P$. heterotremus were isolated from mountain crabs, Potamiscus tannanti, caught from An Lac commune, Luc Yen district, Yen Bai province and from Cam Ngoc commune, Cam Thuy district, Thanh Hoa province. Morphologically, metacercariae from Thanh Hoa province was oval in shape, and union in size $(187-218 \times 164-180 \mu \mathrm{m})$ with the width $<200 \mu \mathrm{m}$ (fig. 1a); while metacecariae from Yen Bai was more round in shape with larger variation of size $(167-300 \times 156-297$ $\mu \mathrm{m})$, thus they were divided into 2 groups: $>200$ $\mu \mathrm{m}$ (fig. 1b) and $<200 \mu \mathrm{m}$ (equal as P. pseudoheterotremus, fig. 1c).

House rats (Rattus tanezumi) caught at 
Ha Noi, where there is no source of Paragonimus infection, BALB/c mice and domestic cats (Felis catus) were used for experimental infection. Experimental animals were shown to be free from Paragonimus by stool examination before experiments.
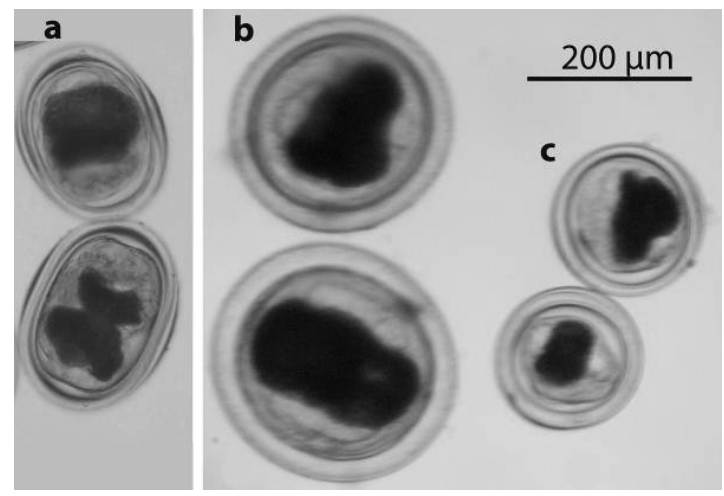

Figure 1. Metacercariae of $P$. heterotremus collected from Thanh Hoa and Yen Bai provinces

a. Metacercariae collected from Thanh Hoa; b-c. Metacercariae collected from Yen Bai showing variation of size.

Infection to animals: metacercariae of each group was counted and given to animals (rats and mice) via oral way after anesthesia.

Five mice and two rats were infected with 20 and 5 metacercariae/animal, respectively, of each metacercaria groups. From day $30^{\text {th }}$ post infection, the feces of experimental animals were checked by sediment technique to find Paragonimus eggs, and one infected mouse of each group was fed to a cat.

After one and two months post infection, two mice of each group were autopsied to identify the development of worms, and experimental animals were autopsied after finding Paragonimus eggs in fecal sample. Flukes were collected from liver, lungs and muscles of the animals. Juvenile worms in muscles and liver were collected by digestion method with pepsin $1 \%$ at $36^{\circ} \mathrm{C}$ for $6-8$ hours to release flukes from the tissues. The flukes were washed by saline $0.9 \%$, then pressed between two glasses, and preserved in $70 \%$ ethanol for pemernant slide by staining with carmine $1 \%$, covered on slide by Canada balsam. The flukes were observed and measured under light microscopic. The data was statistically analyzed using SPSS (Statistical Package for the Social Sciences).

\section{RESULTS AND DISCUSSION}

\section{The result of infection for $B A L B / c$ mice and transfer of juvenile $P$. heterotremus to cats}

The result of autopsy of mice infected with $P$. heterotremus metacercariae showed that all experimental mice become infected with $P$. heterotremus. However, none of the flukes are mature after 60 days; they remain as juveniles in muscles and liver of mice. There was no difference of developmental rates among metacercaria groups. The recovery percentage of metacercariae collected from Thanh Hoa was 56.3\% (including 38.8\% in muscles and $17.5 \%$ in liver). These data are compatible to those $(55.0 \%$ including $41.3 \%$ in muscle and $13.7 \%$ in liver) of metacercariae $>200 \mu \mathrm{m}$ and those $(52.5 \%$ including $40.0 \%$ in muscle and $12.5 \%$ in liver) of metacercariae $<200 \mu \mathrm{m}$ from Yen Bai province (table 1).

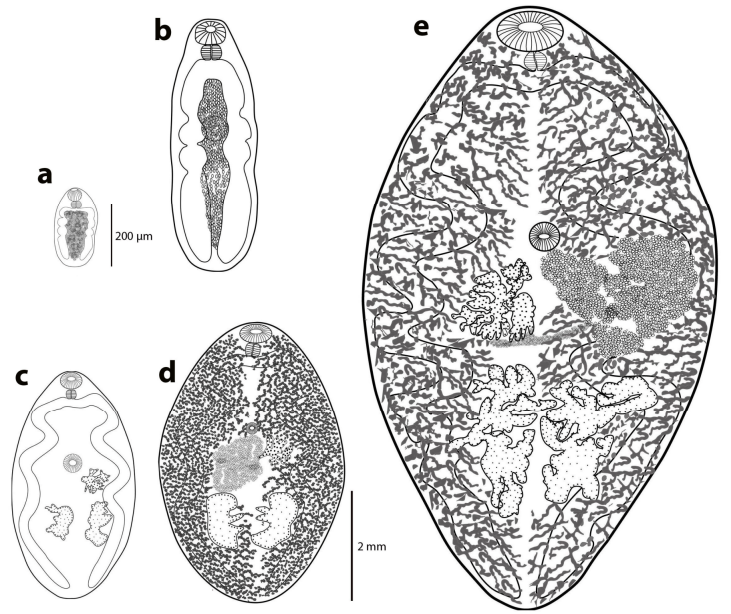

Figure 2. Development of $P$. heterotremus in experimental animals

a. Newly excysted metacercaria; b. Juvenile worm from muscle of mice at 1 month post infection; $c$. Young worm from liver of mice at 1 month post infection (showing testes and ovary); d. Adult worm collected from lung of rat; e. Adult worm collected from lung of cat. Fig. 2a. 2b share the same scale bar (in $\mu \mathrm{m}$ ); Fig. 2c-e share the same scale bar (in $\mathrm{mm}$ ). 
Juvenile worms recovered from muscles (fig. 2b) were morphologically similar to the newly excysted metacercariae (fig. 2a) with the exception that they were slightly larger in size.
There was no statistically significant difference among the size of juvenile worms derived from different metacercaria groups $(p>0.05$, table 2).

Table 1. The result of infection of $P$. heterotremus metacercaria to mice BALB/c

\begin{tabular}{lccccc}
\hline Metacercaria & No. of & No. of Mc/ & \multicolumn{3}{c}{ Number (\%) of juveniles recovered from } \\
\cline { 4 - 6 } collected from & moce* & mouse & Liver & Muscles & Total \\
\hline Thanh Hoa & 5 & 20 & $14(17.5)$ & $31(38.8)$ & $45(56.3)$ \\
Yen Bai, $>200 \mu \mathrm{m}$ & 5 & 20 & $11(13.7)$ & $33(41.3)$ & $44(55.0)$ \\
Yen Bai, $<200 \mu \mathrm{m}$ & 5 & 20 & $10(12.5)$ & $32(40.0)$ & $42(52.5)$ \\
\hline
\end{tabular}

* 1 mouse of each group was fed to cat 1 month post infection; $\mathrm{Mc}=$ Metacercariae.

Table 2. The measurement of worms collected from muscles and liver of mice infected with different metacercaria groups

\begin{tabular}{|c|c|c|c|}
\hline Size & $\begin{array}{l}\text { Worms derived from } \\
\text { metacercaria collected in } \\
\text { Thanh Hoa }\end{array}$ & $\begin{array}{l}\text { Worms derived from } \\
\text { metacercaria }>200 \mu \mathrm{m} \\
\text { collected in Yen Bai }\end{array}$ & $\begin{array}{l}\text { Worms derived from } \\
\text { metacercaria }<200 \mu \mathrm{m} \\
\text { collected in Yen Bai }\end{array}$ \\
\hline \multicolumn{4}{|c|}{ Juvenile from muscles } \\
\hline Body & $\begin{array}{c}760-1000 \times 320-520 \\
(827.5 \times 449.5)\end{array}$ & $\begin{array}{c}704-960 \times 360-536 \\
(846.5 \times 463.8)\end{array}$ & $\begin{array}{c}640-960 \times 320-496 \\
(822.5 \times 446)\end{array}$ \\
\hline Oral sucker & $96-112(108)$ & $96-120(110)$ & $96-112(109)$ \\
\hline $\begin{array}{l}\text { Ventral } \\
\text { sucker }\end{array}$ & $104-128(123)$ & $104-136(124.5)$ & $104-128(123.5)$ \\
\hline \multicolumn{4}{|c|}{ Young worm from liver } \\
\hline Body & $\begin{array}{c}2.4-4.2 \times 1.3-2.0 \\
(3.4 \times 1.8)\end{array}$ & $\begin{array}{c}2.8-4.3 \times 1.2-2.1 \\
\quad(3.4 \times 1.7)\end{array}$ & $\begin{array}{c}2.0-4.6 \times 1.2-2.2 \\
(3.3 \times 1.7)\end{array}$ \\
\hline Oral sucker & $\begin{aligned} 220-320 & \times 340-400 \\
(262 & \times 375)\end{aligned}$ & $\begin{aligned} 220-330 & \times 340-400 \\
(269 & \times 379)\end{aligned}$ & $\begin{array}{c}200-320 \times 300-420 \\
(265 \times 368)\end{array}$ \\
\hline $\begin{array}{l}\text { Ventral } \\
\text { sucker }\end{array}$ & $\begin{array}{l}220-320 \\
(266)\end{array}$ & $\begin{array}{l}220-300 \\
(271)\end{array}$ & $\begin{array}{l}200-360 \\
(280)\end{array}$ \\
\hline Testes & $\begin{aligned} 200-500 & \times 280-700 \\
(382 & \times 541)\end{aligned}$ & $\begin{aligned} 200-500 & \times 300-700 \\
(389 & \times 559)\end{aligned}$ & $\begin{array}{c}200-480 \times 260-720 \\
(386 \times 551)\end{array}$ \\
\hline Ovary & $\begin{array}{c}260-400 \times 300-500 \\
(349 \times 414)\end{array}$ & $\begin{array}{c}280-400 \times 320-510 \\
(360 \times 428)\end{array}$ & $\begin{array}{c}260-420 \times 300-540 \\
(351 \times 408)\end{array}$ \\
\hline
\end{tabular}

Table 3. The result of infection to rat with different metacercaria groups

\begin{tabular}{lcccc}
\hline Metacercaria groups & Number of rat & $\begin{array}{c}\text { Number } \\
\text { of mc/rat }\end{array}$ & $\begin{array}{c}\text { Egg release } \\
(\text { day })\end{array}$ & $\begin{array}{c}\text { Recovery rate } \\
(\%)\end{array}$ \\
\hline From Thanh Hoa & 2 & 5 & $35-40$ & $80-100$ \\
From Yen Bai $>200 \mu \mathrm{m}$ & 2 & 5 & $34-36$ & $40-100$ \\
From Yen Bai $<200 \mu \mathrm{m}$ & 2 & 5 & $35-41$ & $60-80$ \\
\hline
\end{tabular}

Flukes collected from liver (fig. 2c) were bigger than juvenile worms from muscles, and reproduction organs (testes and ovary) were observed. There was no statistically significant difference among the size of young flukes derived from different metacercaria groups $(p>0.05$, table 3$)$.

The result of re-infection to cats with juvenile worms from mice of the previous infection showed that all three cats fed the mice, 
which were previously infected with different metacercaria groups from Thanh Hoa and Yen Bai, became infected with adults of $P$. heterotremus. The time of releasing egg was 45-60 days post infection, and the developmental rates were $10-20 \%$. The flukes are oval in shape, body size $10-15 \mathrm{~mm}$, ovary and testes branched, vitelline well-developed and uterus is full of eggs (fig. 2e).

Table 4. Measurement of worms collected from lung of rats infected with different metaceracria groups

\begin{tabular}{lccc}
\hline Size & $\begin{array}{c}\text { Worms derived from } \\
\text { metacercariae from } \\
\text { Thanh Hoa }\end{array}$ & $\begin{array}{c}\text { Worms derived from } \\
\text { metacercariae }>200 \mu \mathrm{m} \\
\text { from Yen Bai }\end{array}$ & $\begin{array}{c}\text { Worms derived from } \\
\text { metacercariae }<200 \mu \mathrm{m} \\
\text { from Yen Bai }\end{array}$ \\
\hline Body & $4.5-5.3 \times 3-3.5$ & $4.8-5.5 \times 3-3.5$ & $5-5.4 \times 2.8-3.6$ \\
& $(4.9 \times 3.3)$ & $(5.1 \times 3.3)$ & $(5.2 \times 3.4)$ \\
Oral sucker & $360-420 \times 500-700$ & $360-400 \times 520-720$ & $380-400 \times 520-700$ \\
& $(388 \times 648)$ & $(388 \times 668)$ & $(396 \times 664)$ \\
Ventral & $360-400$ & $360-400$ & $380-400$ \\
sucker & $(380)$ & $(384)$ & $(396)$ \\
Testes & $960-1100 \times 720-980$ & $980-1200 \times 720-1000$ & $1000-1200 \times 700-1000$ \\
& $(1052 \times 812)$ & $(1120 \times 840)$ & $(1100 \times 820)$ \\
Ovary & $500-660 \times 560-680$ & $580-720 \times 580-680$ & $600-700 \times 600-700$ \\
& $(588 \times 604)$ & $(620 \times 612)$ & $(620 \times 620)$ \\
\hline
\end{tabular}

The result of infection for rats (Rattus tanezumi)

Paragonimus eggs were detected from fecal samples of all six experimental rats infected with $P$. heterotremus metacercariae. Two ratsinfected with metacercariae from Thanh Hoa released Paragonimus eggs at 35-40 days post infection, and the rates of metacercariae developed to adult were $80-100 \%$. These data were similar to those (produced eggs after 34-36 days with developmental rate of $40-100 \%)$ of metacercariae $>200 \mu \mathrm{m}$ and those (produced eggs after 35-41 days and developmental rate of $60-80 \%$ ) of metacercariae $<200 \mu \mathrm{m}$ from Yen Bai (table 4). There was no statistically significant difference among the size of flukes derived from different metacercaria groups $(p>0.05$, table 4). Adults collected from rats (fig. 2d) are smaller than those of adults recovered from cats (fig. 2e).

\section{DISCUSSION}

Paragonimus heterotremus is the pathogen for human paragonimiasis from South to Southeast Asia and Southern China [2]. Among species of the genus Paragonimus, $P$. heterotremus is typical by the smallest metacercariae $(<300 \mu \mathrm{m})$ in comparison with other reported species. Recently, a new species, $P$. pseudoheterotremus, was described from Thailand having metacercariae (about $200 \mu \mathrm{m}$ ) slightly smaller than that of $P$. heterotremus, although they showed similarity in morphology of adults and ITS2 sequence to each other [20, 21]. Biologically, P. pseudoheterotremus and $P$. heterotremus from Thailand are considered to be different from each other in susceptibility to rodent hosts. The former species can develop to adults in rats, but the latter one can not [21]. Since, the range of size of $P$. heterotremus metacercariae from Vietnam cover the size of P. pseudoheterotremus, it is important to clarify if there is $P$. pseudoheterotremus in Vietnam, and if there is any difference among development of different-size group of metacercariae in rats. The result of present study clearly showed that there is no difference among the development of different-size $P$. heterotremus metacercaria groups in rats and mice, although they are various in morphology and size. 
The size of $P$. pseudoheterotemus metacercariae was considered to be slightly smaller than that of $P$. heterotremus. However, this comparison was made from specimen within Thailand only. When gathering all available data from various geographical locations, Doanh et al. (2013) [6] found that the size of $P$. pseudoheterotremus metacercariae is almost equal to that of $P$. heterotremus from China [11], India [17] and from Thanh Hoa, Vietnam [6]. Moreover, the variations of susceptibility of $P$. heterotremus to rats have been recorded. Sugiyama et al. (1990) [18] reported that Wistar rat was not sensitive to $P$. heterotremus from Thailand; they did not develop to adults. In contrast, $\mathrm{Hu}$ (1998) [11] and Yan et al. (1998) [19] found the sensitivity of Wistar rat to $P$. heterotremus from China. In India, $P$. heterotremus collected from Manipur did not mature in rats [16], while metacercariae from Arunachal Pradesh developed to adults [15]. The difference in host specificity among geographical populations was also seen in $P$. westermani $[8-10,14]$. Thus, the slight variation of the size of metacercariae and susceptibility to experimental rats cannot be employed to separate $P$. pseudoheterotremus as a valid species; it should be a geographical population of $P$. heterotremus as confirmed by molecular analyses [6].

In this study, all metacercaria groups developed to adults in rats with high rates (up to $100 \%$ ), and the time required for $P$. heterotremus to be mature in rats is shorter than that in dog and cats [7], confirming that rats can play the role as definitive host of $P$. heterotremus in Vietnam. In contrast, $P$. heterotremus metacercariae did not develop to adults in mice; they remain as juvenile worms in muscles and liver. When these juveniles were transferred from mice to cats, they develop to adults, indicating that mice play the role as paratenic hosts in the life cycle of $P$. heterotremus in Vietnam. More extensive survey for natural paratenic hosts of $P$. heterotremus is, therefore, necessary.

To date, P. heterotremus has been detected in Northern Vietnam, and proved to be pathogen for human paragonimiasis. The number of detected cases have been increased, especially in Lai Chau (Sin Ho), Son La, Lao Cai, Yen Bai [3]. Previous studies in Vietnam just propagated not eating undercooked mountain crabs to avoid paragonimus infection. The results of this study suggests that not eating uncooked meat of other animals in addition to mountain crabs should be added to prevent of paragonimus infection.

\section{CONCLUSION}

Metacercariae of $P$. heterotremus showed variation in morphology and size, but similarity in their development in house rats and mice.

In experiments, house rats play as definitive hosts of $P$. heterotremus. In contrast, mice play the role as paratenic host of this parasite.

Acknowledgment: This study was supported by Vietnam National Foundation for Science and Technology Development (No. 106.122012.52).

\section{REFERENCES}

1. Blair D., Agatsuma T., Wang W., 2007. Paragonimiasis. In; (Murrell KD and Fried B eds.) World Class Parasites Vol. 11, Food-borne parasitic zoonoses. Springer, NY:117-150.

2. Blair D., Xu Z. B., Agatsuma T., 1999. Paragonimiasis and the genus Paragonimus. Adv. Parasitol., 42: 113-222.

3. De N. V., Cong L. D., Kino H., Son D. T., Vien H. V., 2000. Epidemiology, symptoms and treatment of paragonimiasis in Sin Ho district, Lai Chau province, Vietnam. Southeast Asian J. Trop. Med. Public Health, 31(1): 26-30.

4. Doanh P. N., Horii Y., Nawa Y., 2013. Paragonimus and paragonimiasis in Vietnam: an update. Korean J. Parasitol., 51(6): 621-627.

5. Doanh P. N., Thach D. T. C., Shinohara A., Horii Y., Nawa Y., 2011. Human paragonimiasis in Vietnam: Epidemiological survey by egg finding/dot ELISA and species identification based on ITS2 and CO1 sequences of Paragonimus 
eggs from sputum of patients. Parasitol. Int., 60(4): 534-537.

6. Doanh P. N., Thaenkham U., An P. T., Hien H. V., Horii Y., Nawa Y., 2013. Metacercarial polymorphism and genetic variation of Paragonimus heterotremus, and re-appaisal of the taxonomic status of $P$. pseudoheterotremus. J. Helminthol., DOI 10.1017/S0022149X13000734.

7. Pham Ngoc Doanh, Nguyen Thi Le, Dang Tat The, 1999. Development of lung fluke Paragonimus heterotremus in animals and their damage. Tap chi Sinh hoc, 21(2b): 7682 (Vietnamese with English summary).

8. Habe S., 1978. Experimental studies on the mode of human infection with the lung fluke, Paragonimus westermani. Jpn. J. Parasitology, 27: 261-292 (Japanese with English abstract).

9. Habe S., 1983. A newly recognized paratenic host of Paragonimus spp. Japan J. Trop. Med. Hyg., 11(1): 1-6.

10. Habe S., Lai K. P. F., Agatsuma T., OwYang C. K., Kawashima K., 1996. Growth of Malaysian Paragonimus westermani in mammals and the mode of transmission of the fluke among mammals. Jpn. J. Trop. Med. Hyg., 24(4): 225-232 (Japanese with English abstract).

11. Hu W., 1998. Studies on the life cycle of Paragonimus heterotremus. Chinese journal of parasitology \& parasitic diseases 16: 347 352 (Chinese with English abstract).

12. Le T. H., De N. V., Blair D., McManus D. P., Kino H., Agatsuma T., 2006. Paragonimus heterotremus Chen et Hsia, 1964 in Vietnam: A molecular identification and relationships of isolates from different hosts and geographical origins. Acta. Trop., 98: 25-33.

13. Le N. T., The D. T., Doanh P. N., 1997. Infection status of Paragonimus metacercariae in crab hosts in Sin Ho - Lai Chau. Journal of
Practical Medicine, 2: 35-40.

14. Miyazaki I., Habe S., 1979. Paragonimus westermani filipinus Miyazaki, 1978 sat. n. occurring at Jaro, Leyte, The Philippines. Med. Bull. Fukuoka Univ., 6: 447-462 (Japanese with English abstract).

15. Narain K., Devi K. R., Mahanta J., 2003. Paragonimus and paragonimiasis: a new focus in Arunachal Pradesh, India. Curr. Sci., 84: 985-987.

16. Singh T. S., Singh Y. I., 1997. Three types of Paragonimus metacercariae isolated from Potamiscus manipurensis, in Manipur. Indian J. Med. Microbiol., 15: 159-162.

17. Singh T. S., Sugiyama H., Rangsiruji A., Devi K. R., 2007. Morphological and molecular characterizations of Paragonimus heterotremus, the causative agent of human paragonimiasis in India. Southeast Asian J. Trop. Med. Public Health, 38: 82-86.

18. Sugiyama H., Shibahara T., Katahira J., Horiuchi T., Tomimura T., Agatsuma T., Habe S., Kawashima K., Ketudat P., Thaithong S., 1990. Rats and mice served as experimental paratenic hosts of Thai Paragonimus heterotremus. Jpn. J. Trop. Med. Hyg., 18: 295-300.

19. Yan T., Li G., Dong C., 1998. Experimental studies on development of Paragonimus heterotremus in rats. Chinese journal of parasitology \& parasitic diseases, 16: 126-129 (Chinese with English abstract).

20. Thaenkham U., Waikagul J., 2008. Molecular phylogenetic relationship of Paragonimus pseudoheterotremus. Southeast Asian J. Trop. Med. Public Health, 39: 217-221.

21. Waikagul J., 2007. A new species of Paragonimus (Trematoda: Troglotrematidae) from a cat infected with metacercariae from mountain crabs Larnaudia larnaudii. J Parasitol., 93: 1496-500. 


\title{
SỰ PHÁT TRIỂN CỦA SÁN LÁ PHỔI, Paragonimus heterotremus, Ở CHUỘT THÍ NGHIỆM VÀ VAI TRÒ VẠTT CHỦ DỬ TRŨ TRONG VÒNG ĐỜI PHÁT TRIỄN CỦA CHÚNG
}

\author{
Phạm Ngọc Doanh ${ }^{1}$, Hoàng Văn Hiền ${ }^{1}$, Phạm Thành $\mathrm{An}^{2}$, Lưu Anh Tú ${ }^{3}$ \\ ${ }^{1}$ Viện Sinh thái và Tài nguyên sinh vật, Viện Hàn lâm KH \& CN Việt Nam \\ ${ }^{2}$ Trạm Kiểm dịch động vật Nội Bài \\ ${ }^{3}$ Bệnh viện Phồi Trung ương
}

\section{TÓM TẮT}

Loài sán lá phổi, Paragonimus heterotremus, được khẳng định là nguyên nhân gây bệnh sán lá phổi cho người và động vật. Ở các tỉnh miền Bắc Việt Nam, người nhiễm bệnh đã được xác định là do ăn cua núi (vật chủ trung gian 2) bị nhiễm ấu trùng chưa được nấu chín. Trong nghiên cứu này, chúng tôi xác định vai trò vật chủ dự trữ trong vòng đời phát triển của sán lá phổi $P$. heterotremus bằng cách gây nhiễm cho chuột, sau đó gây nhiễm chuyển tiếp cho mèo. Kết quả cho thấy, $P$. heterotremus phát triển đến trưởng thành ở chuột nhà, nhưng tồn tại ở dạng sán non ở cơ và gan chuột bạch. Khi gây nhiễm chuyển tiếp sán non từ chuột bạch cho mèo, chúng phát triển đến trưởng thành. Điều đó khẳng định vai trò vật chủ dự trữ trong vòng đời phát triển của sán lá phổi $P$. heterotremus ở Việt Nam, người và động vật có thể bị nhiễm bệnh do ăn phải vật chủ dự trữ mang mầm bệnh sán lá phổi. Vì vậy, điều tra xác định vật chủ dự trữ của sán lá phổi ngoài tự nhiên là việc cần thiết và để phòng tránh nhiễm sán lá phổi, ngoài việc không ăn cua núi chưa nấu chín kỹ, cần tránh ăn sống hoặc tái thịt các loài động vật khác. Nghiên cứu này cũng khẳng định không có khác biệt về sự phát triển của các nhóm metacercaria kích thước khác nhau của loài $P$. heterotremus.

Tù khóa: Paragonimus heterotremus, chuột bạch, chuột nhà, sán lá phổi, sự phát triển, vật chủ chứa.

Ngày nhận bài: 9-5-2015 